\title{
MORE ABOUT BUTTERFLY BOOKS AND A MAGAZINE
}

BERNIE GOLLOP, 2202 York Avenue, Saskatoon, Saskatchewan. S7J 1J1

This article reviews five regional identification guides not included in my June 1989 synopsis in Blue Jay, a caterpillar guide and a magazine. ${ }^{2}$ It also compares the species coverage for each of the prairie provinces in eight major field guides. But first, a book about names.

\section{THE COMMON NAMES OF NORTH} AMERICAN BUTTERFLIES. J.Y. Miller. 1992. Smithsonian Institution, Washington, DC. 177 pp. $(155 \times 230$ mm) $\$ 20$ US.

One curse of the insect world is the variety of names, both scientific and English (common), for one animal. For instance, Arctic Blue appears in all eight of the guides in the tables below but under six common names and five scientific names. So, to compare a species from one guide to another, you may have to check both common and scientific name. The sequence of butterfly groups may also change from book to book, making it difficult to learn where to look for a species.

This volume was the first step toward standardizing English butterfly names. For each species the most frequently published name is proposed as the common name. Beneath it are listed many of the alternatives (with scientific names) used over the years. Each synonym gives the book it was taken from so that the reader knows what name to look up in each title. (None of the prairie province guides were included.) To facilitate finding a particular butterfly by any other name, there is a 58-page index.

(The second step was taken by the newly formed North American Butterfly Association [NABA] which looked at Miller's list and came up with more appropriate names for some species. Their efforts have been published in American Butterflies [see below] and may soon appear as a separate checklist for North America. ${ }^{6}$ Hopefully this list will receive as widespread acceptance and use as the American Ornithologists' Union's bird names.)

BUTTERFLIES OF ALBERTA. John Acorn. 1993. Lone Pine, Edmonton, Alberta. 143 pp. Colour photos, black-and-white sketches. (140 x $215 \mathrm{~mm}$ ) \$17 Cdn.

This is an attractive, softcover book. Its introduction includes sections on butterfly habitats and seasons, butterflies vs. moths, butterfly life cycles, enemies and behaviour, and enjoying butterflies - watching, gardening for and photographing. It concludes with a glossary, an index and a checklist. The major section on species makes 




North American butterfly identification guides. Clockwise from upper left:

Tilson's Western Peterson, Pyle's North American, Scott's North American,

Opler's Eastern Peterson.

B.J. Gollop

interesting reading and presents a range map for each butterfly. Included are caterpillar and adult food plants.

There are a few problems. For instance: how many species are found in Alberta? "[S]ome 156," according to the introduction. However, the checklist gives 162 species. The text indicates that two of these (Pahaska Skipper and Northern Pearly Eye) have not yet been found and I could not locate the other two (Dun Skipper and Dog Face) elsewhere in the book. This volume would indicate that there are 158 species found in Alberta.

Unfortunately, this guide fails to illustrate a significant portion of Alberta's butterflies. Six species are not described and $20 \%$ are treated with text alone, often inadequately. Furthermore, an illustration, whether of a living butterfly or a sketch, usually displays only one surface of one sex. Two photos are not identified Roadside Skipper (p. 42) and White Admiral (p. 109). On p. 98, Sagebrush Checkerspot is named, apparently meaning Acastus Checkerspot.

There is a map for every species (except Edith's Copper) but the maps are so small - $15 \mathrm{~mm}$ high and lack landmarks, such as Edmonton, Calgary, or any river systems, that their usefulness is significantly reduced.

Because scientific names are a necessary evil, it would have been more convenient if they had appeared in the main text when 


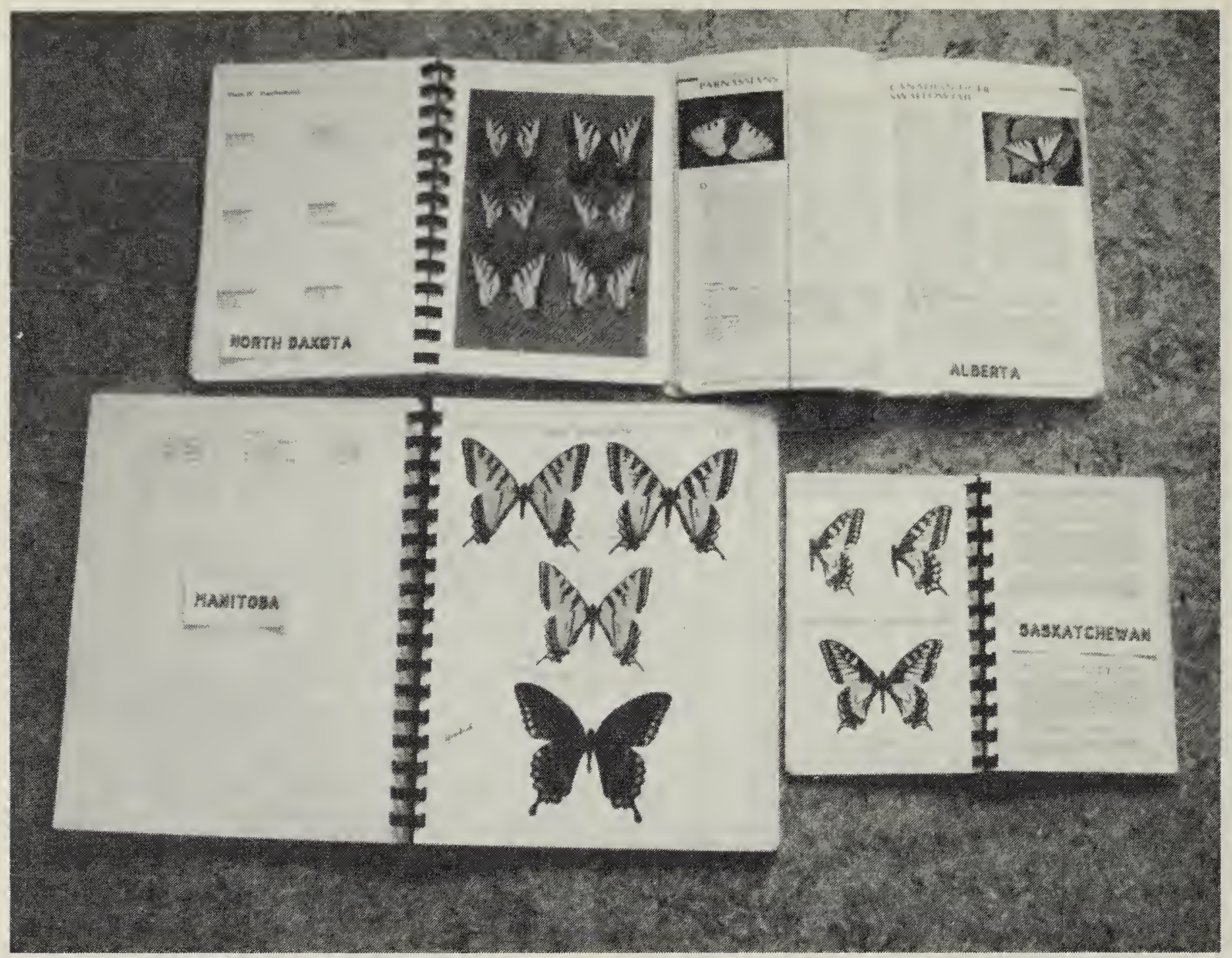

Provincial/state butterfly identification guides. 'Clockwise from upper left:

Royer's North Dakota, Acorn's Alberta, Hooper's Saskatchewan,

Klassen's Manitoba.

B.J. Gollop

species are first discussed, rather than in the checklist.

The strengths of Butterflies of Alberta are that it lists the species found, tells where and when to find them, and gives hints on plants for butterfly gardeners.

\section{A FIELD GUIDE TO EASTERN BUTTERFLIES (Peterson Field} Guide Series). P.A. Opler and Vichai Malikul. 1992. Houghton Mifflin, Boston. 396 pp. plus 48 colour plates. $(114 \times 182 \mathrm{~mm}) \$ 24 \mathrm{Cdn}$.

This is not a revision of Peterson's 40-year-old eastern butterfly book. ${ }^{5}$ It is a completely new guide - fully illustrated in colour with paintings. It covers "all species documented in the east" - east of the 100th Meridian (through Brandon, MB), including practically all of Manitoba's butterflies, $85 \%$ of Saskatchewan's and $73 \%$ of Alberta's.

There are sections on life history; watching, photographing, collecting; gardening; conservation; habitats; glossary; checklist; directory of butterfly societies; and index to host and nectar plants. There are also colour photos of 9 butterfly flowers, 18 larvae, 9 chrysalids and 68 live butterflies.

Both upper and lower surfaces (half butterflies) of one sex are usually shown and each is identified by name on the plate (unlike the Western Peterson, where images are numbered). These illustrations are not enough in cases where male and female are different. All species on a plate are to the same scale. Typical 
Table 1. PERCENTAGE OF PROVINCIAL SPECIES

TREATED IN EIGHT BUTTERFLY IDENTIFICATION GUIDES

Sequence: Total \% treated (\% of provincial species in colour/black-and-white/adequate text only) ${ }^{\star}$

\begin{tabular}{|c|c|c|c|c|}
\hline Butterflies of: & Alberta & Saskatchewan & Manitoba & Images/species \\
\hline No. species: ${ }^{\star \star}$ & 159 & 151 & 144 & usual/range \\
\hline GUIDE & $\%$ & $\%$ & $\%$ & Number \\
\hline $\begin{array}{l}\text { North Americal } \\
\text { Scott }\end{array}$ & $\begin{array}{c}100 \\
(99 / 1 /-)\end{array}$ & $\begin{array}{c}100 \\
(99 / 1 /-) \\
\end{array}$ & $\begin{array}{c}100 \\
(99 / 1 /-)\end{array}$ & $3-4 / 1-14$ \\
\hline $\begin{array}{l}\text { North Americal } \\
\text { Pyle }\end{array}$ & $\begin{array}{c}99 \\
(94 / 4 / 2) \\
\end{array}$ & $\begin{array}{c}100 \\
(95 / 3 / 2) \\
\end{array}$ & $\begin{array}{c}100 \\
(97 / 4 /-)\end{array}$ & $2-1 / 1-5$ \\
\hline $\begin{array}{l}\text { Western } \\
\text { Peterson/Tilden }\end{array}$ & $\begin{array}{c}97 \\
(63 / 34 /-) \\
\end{array}$ & $\begin{array}{c}95 \\
(58 / 37 /-) \\
\end{array}$ & $\begin{array}{c}92 \\
(63 / 29 /-)\end{array}$ & $2-1 / 1-13$ \\
\hline $\begin{array}{l}\text { Eastern } \\
\text { Peterson/Opler }\end{array}$ & $\begin{array}{c}73 \\
(70 /-13) \\
\end{array}$ & $\begin{array}{c}85 \\
(82 /-13) \\
\end{array}$ & $\begin{array}{c}97 \\
(96 /-/ 1) \\
\end{array}$ & $2 / 1-5$ \\
\hline $\begin{array}{l}\text { Albertal } \\
\text { Acorn }\end{array}$ & $\begin{array}{c}94 \\
(51 / 23 / 20)\end{array}$ & $\begin{array}{c}68 \\
(44 / 14 / 10) \\
\end{array}$ & $\begin{array}{c}79 \\
(50 / 17 / 13) \\
\end{array}$ & $1 / 1-4$ \\
\hline $\begin{array}{l}\text { Saskatchewan/ } \\
\text { Hooper }\end{array}$ & $\begin{array}{c}73 \\
(9 / 64 / 1) \\
\end{array}$ & $\begin{array}{c}97 \\
(11 / 81 / 5) \\
\end{array}$ & $\begin{array}{c}77 \\
(10 / 66 / 1) \\
\end{array}$ & $3-2 / 1-4$ \\
\hline $\begin{array}{l}\text { Manitoba/ } \\
\text { Klassen }\end{array}$ & $\begin{array}{c}66 \\
(66 /-/-) \\
\end{array}$ & $\begin{array}{c}78 \\
(78 /-1-)\end{array}$ & $\begin{array}{c}99 \\
(99 /-/-)\end{array}$ & $3-4 / 1-10$ \\
\hline $\begin{array}{l}\text { North Dakotal } \\
\text { Royer }\end{array}$ & $\begin{array}{c}59 \\
(57 / 1 /-)\end{array}$ & $\begin{array}{c}73 \\
(72 / 1 /-)\end{array}$ & $\begin{array}{c}72 \\
(71 / 1 /-) \\
\end{array}$ & $3 / 1-16$ \\
\hline * Total does no & qual three & because $c$ & $g$ off. & \\
\hline
\end{tabular}

of the Peterson series, arrows point out diagnostic field marks and the facing text enlarges them. These features are most useful.

\section{BUTTERFLIES OF NORTH} DAKOTA - AN ATLAS AND GUIDE. R.A. Royer. 1988. Minot State University. Minot, ND. 193 pp. 1 black-and-white and 12 colour plates $(145 \times 203 \mathrm{~mm}) \$ 20 \pm$ US.

The 142 species of North Dakota butterflies are illustrated by coloured photos. The pictures are excellent, if small. Two plates each have more than 50 images of pinned specimens. There are 1 to 16 pictures per species, with an average of 3 . There is a map for each species (in a separate, paper-wasting section) with distribution designated by county. A most significant drawback is that itlustrations and maps are identified by scientific names only.
Seventy-two percent of Manitoba's butterflies are illustrated, $73 \%$ of Saskatchewan's, and 59\% of Alberta's.

BUTTERFLIES THROUGH BINOCULARS. A FIELD GUIDE TO BUTTERFLIES IN THE BOSTONNEW YORK-WASHINGTON REGION. Jeffrey Glassberg. 1993. Oxford University Press, New York. $160 \mathrm{pp}$. plus 40 plates of coloured photos $(140 \times 210 \mathrm{~mm}) \$ 17$ US.

While not particularly pertinent as a guide to our region, this book deserves mention for its approach field marks as seen through binoculars. A major requirement for butterfly binoculars is a short focus distance. Bausch and Lomb $7 \times 26$ Custom Compact, Nikon $8 \times 20$ folding and Minolta "Pocket" binoculars are among the models that focus down to about $6 \mathrm{ft}$. Note: this distance can vary even among 


\section{Table 2. COMPARISON OF TEXTUAL INFORMATION IN EIGHT BUTTERFLY IDENTIFICATION GUIDES*}

\begin{tabular}{|c|c|c|c|c|}
\hline Information on: & Subspecies & Larva Desc. & Food $\mathrm{Yg} / \mathrm{Ad} / \mathrm{Index}$ & Range Map/Text \\
\hline $\begin{array}{l}\text { North Americal } \\
\text { Scott }\end{array}$ & best & $x$ & $X /-/ 19 p p$ & NA/NA \\
\hline $\begin{array}{l}\text { North America/ } \\
\text { Pyle }\end{array}$ & - & - & $X /-/ 19 p p$ & $-/ N A$ \\
\hline $\begin{array}{l}\text { Western } \\
\text { Peterson/Tilden }\end{array}$ & $x$ & $x$ & $\mathrm{X} /-/ 8 \mathrm{pp}$ & -/WNA \\
\hline $\begin{array}{l}\text { Eastern } \\
\text { Peterson/Opler }\end{array}$ & - & $x$ & $X /-/ 6 p p$ & ENA/ENA \\
\hline $\begin{array}{l}\text { Albertal } \\
\text { Acorn }\end{array}$ & - & - & $X / X /-$ & $\mathrm{AB} /-$ \\
\hline $\begin{array}{l}\text { Saskatchewan/ } \\
\text { Hooper }\end{array}$ & $x$ & - & $\mathrm{X} / \mathrm{X} / 2 \mathrm{pp}$ & -INA,SK \\
\hline $\begin{array}{l}\text { Manitoba/ } \\
\text { Klassen }\end{array}$ & $x$ & $x$ & $X / X / 5 p p$ & MB/NA,MB \\
\hline $\begin{array}{l}\text { North Dakota/ } \\
\text { Royer }\end{array}$ & - & - & $\mathrm{X} /-1-$ & $\mathrm{ND} /-$ \\
\hline Information on: & $\begin{array}{c}\text { Biology, } \\
\text { Ecology, Studying }\end{array}$ & Glossary of Terms & Bibliography & Remarks \\
\hline $\begin{array}{l}\text { North Americal } \\
\text { Scott }\end{array}$ & 132pp & $8 p p$ & $3 p p$ & Keys: 33pp \\
\hline $\begin{array}{l}\text { North America/ } \\
\text { Pyle }\end{array}$ & $28 p p$ & $8 p p$ & - & \\
\hline $\begin{array}{l}\text { Western } \\
\text { Peterson/Tilden** }\end{array}$ & $28 p p$ & $4 p p$ & $6 p p$ & \\
\hline $\begin{array}{l}\text { Eastern } \\
\text { Peterson/Opler }\end{array}$ & $41 p p$ & $6 p p$ & $4 p p$ & $\begin{array}{c}\text { Lists of societies } \\
\& \text { suppliers }\end{array}$ \\
\hline $\begin{array}{l}\text { Alberta/ } \\
\text { Acorn }\end{array}$ & $15 p p$ & $3 p p$ & - & \\
\hline $\begin{array}{l}\text { Saskatchewan/ } \\
\text { Hooper }\end{array}$ & $13 p p$ & - & - & \\
\hline $\begin{array}{l}\text { Manitoba/ } \\
\text { Klassen }\end{array}$ & $8 p p$ & $2 p p$ & $5 p p$ & \\
\hline $\begin{array}{l}\text { North Dakotal } \\
\text { Royer }\end{array}$ & $3 p p$ & $6 p p$ & - & $\begin{array}{l}\text { Lists of societies } \\
\& \text { suppliers }\end{array}$ \\
\hline $\begin{array}{l}\text { * All have adult des } \\
\text { ** Arrows point to } \\
\text { X Usually } \\
\text { - Not at all or rarel }\end{array}$ & $\begin{array}{l}\text { cription, similar spec } \\
\text { eld marks }\end{array}$ & ies, flight periods, ha & abitat and collecting & see text) \\
\hline
\end{tabular}

glasses of the same model, so check more than one if you can.

As the vanguard of future regional lists, this volume includes bar graphs of relative abundance for each of five years by five-day periods and descriptions of nine sites with a checklist for each.

On average, there are two excellent colour photos of living butterflies for each of 150 species. The book illustrates $59 \%$ of Manitoba's butterflies, $49 \%$ of Saskatchewan's, and $32 \%$ of Alberta's. 
BUTTERFLIES EAST OF THE GREAT PLAINS. AN ILLUSTRATED NATURAL HISTORY. P.A. Opler and G.O. Krizek. 1984. John Hopkins University, Baltimore. 294 pp. plus 54 plates of coloured photos $(220 \times 285 \mathrm{~mm})$. \$66 Cdn.

The area of emphasis is the United States, east of the Mississippi River. Minnesota is the state closest to the prairie provinces. This book presents 317 colour photos (many 2 to 4 times life size) for 199 of the 292 species covered. Maps are shown for 274 butterflies.

A unique feature is the derivation of each scientific name. Strong points are the Life History section (behaviour, broods, early stages, etc.) and adult nectar sources for each species.

There are images for $67 \%$ of Manitoba's butterflies, $54 \%$ of Saskatchewan's and $39 \%$ of Alberta's. However, an additional 32 prairie province species are treated in the text with maps.

\section{PETERSON FIRST GUIDE TO CATERPILLARS OF NORTH AMERICA. A.B. Wright. 1993.} Houghton Mifflin, Boston. 128 pp. 55 colour plates (95 x $185 \mathrm{~mm}$ ) \$6 Cdn.

This book covers the 120 most common larvae - butterflies (57) and moths (63). For each species the author paints adult and larva, often a pupa, chrysalis or cocoon, and sometimes eggs. Text faces paintings, with one to four species per pair of pages. Food plants are given for each species but no index for those is included. Scientific names appear in the species index.

Caterpillars are treated in ten groups, based on appearance smooth, hairy, with spines, etc. One learns that the caterpillars for such different looking butterflies as Viceroy and White Admiral are "identical," and look "like bird droppings." And that the Wooly Bear grows into the Isabelle Tiger Moth. One hopes that a much more complete caterpillar guide is forthcoming.

AMERICAN BUTTERFLIES. A magazine, published quarterly by the North American Butterfly Association (a non-profit organization), 4 Delaware Road, Morristown, NJ, 07960. $36 \mathrm{pp}$. per issue, maps and many black-and-white photos. Canadian subscription: \$25 US.

The first four issues of this magazine appeared in 1993. There are five or six articles per issue, an editorial, book reviews, letters, and a section on the English names of butterflies.

Subjects have included: starting your own butterfly club, binoculars and video cameras for butterflying, tracking North American Monarchs, the international July 4th butterfly count, raising caterpillars, identification of difficult groups, and descriptions of good butterfly locations in detail along with their butterflies. For instance: a nature reserve $30 \mathrm{mi}$ from New York City hosts 84 species (about 70 can be expected within $55 \mathrm{~km}$ of Saskatoon). A 600-acre state park in Texas has 164 species, 13 more than in all of Saskatchewan.

This is an interesting magazine for anyone, particularly amateurs, who enjoy butterflies.

Field guides for the prairie provinces:

More so than birders, butterfliers need more than one field guide, both because upper and lower surfaces of 
male and female butterflies are seldom illustrated in one volume and because colour and pattern for a species may vary by season and from region to region. With that in mind, Table 1 is presented, giving the proportions of each province's butterflies treated in eight guides. ${ }^{1,3,4,7,8,9,10,11}$ The number of species per province is based on NABA decisions as to what is a species and what is a subspecies and includes additions through 1993 to prairie fauna. Also included is the number of images (whole or half butterflies) of a species - the more, the better.

An outline of additional contents in each guide is presented in Table 2 . Using the Eastern Peterson as an example, the table reads as follows: For each species, the guide treats adults, similar species, flight period and collecting; images have arrows pointing to important field marks; it seldom lists subspecies, usually gives food plants of larva but, rarely, nectar plants of adult; it includes a six-page index of host plants; both map and range in the text are restricted to eastern North America; there is an introductory 41-page discussion of biology, ecology, and studying (including one or more of watching, conservation, gardening and photographing); a 6-page glossary; a 4-page bibliography, and lists of pertinent societies and suppliers of equipment. (The Western Peterson and North Dakota guides also have this last feature.)

The best field guides for each province? Why not? - if you will settle for just one person's opinion. 1) Your provincial guide. 2) \& 3) For Alberta, Pyle and the Western Peterson guides; for Saskatchewan, Pyle and Manitoba guide; and for Manitoba, Pyle and Eastern Peterson. (Scott is probably a better guide than Pyle but it is more a cumber- some home reference rather than a field guide. It is particularly good at describing and illustrating subspecies and detailing life histories.)

All the books above and below are softcover (except for Klotz).

1. ACORN, J. 1993. Butterflies of Alberta. Lone Pine, Edmonton, Alberta. 143 pp. Colour photos, black-andwhite sketches. $(141 \times 215 \mathrm{~mm}) \$ 17$ Cdn.

2. GOLLOP, B. 1989. A selected, annotated bibliography for Saskatchewan butterfly watchers. Blue Jay 47:83-88.

3. HOOPER, R.R. 1973. Butterflies of Saskatchewan - a field guide. Royal Saskatchewan Museum, Regina. 216 pp. $(114 \times 72 \mathrm{~mm}) \$ 4 \mathrm{Cdn}$.

4. KLASSEN, P., A.R. WESTWOOD, W.B. PRESTON, and W.B. MCKILLOP. 1989. Butterflies of Manitoba. Manitoba Museum of Man and $\mathrm{Na}$ ture, Winnipeg. 290 pp. (204 × 254 $\mathrm{mm}) \$ 22 \mathrm{Cdn}$.

5. KLOTZ, A.B. 1951. A field guide to the butterflies of North America, east of the Great Plains. Houghton Mifflin, Boston. 349 pp. $(120 \times 190 \mathrm{~mm})$. Out of print.

6. NORTH AMERICAN BUTTERFLY ASSOCIATION. 1994. Collated list of English names for North American butterflies. American Butterflies 2(2):28-35.

7. OPLER, P.A. and V. MALIKUL. 1992. A field guide to eastern butterflies. (Peterson Field Guide series). Houghton Mifflin, Boston. 396 pp. $(114 \times 182 \mathrm{~mm}) \$ 21 \mathrm{Cdn}$.

8. PYLE, R.M. 1981. The Audubon Society field guide to North American butterflies. Knopf, NY. 924 pp. $(102 x$ $192 \mathrm{~mm})$ \$21 Cdn.

9. ROYER, R.A. 1988. Butterflies of North Dakota. An atlas and guide. Minot State University, Minot, ND. 192 pp. 12 colour and 1 black-and-white plates. $(141 \times 215 \mathrm{~mm}) \$ 20 \pm$ US.

10. SCOTT, J.A. 1986. The butterflies of North America. A natural history and field guide. Stanford University, Stanford, CA. 583 pp. $(195 \times 260 \mathrm{~mm}) \$ 50$ US.

11. TILDEN, J.W., and A.C. SMITH. 1986. Field guide to western butterflies. (Peterson Field Guide series). Houghton Mifflin, Boston. $370 \mathrm{pp}$. $(114 \times 182 \mathrm{~mm})$ \$23 Cdn. 